\title{
PERIOPERACINIS SKAUSMO VALDYMAS INTRAOPERACINIU KETAMINU, ATLIEKANT STUBURO FIKSACIJOS OPERACIJAS: BANDOMOJI STUDIJA
}

\author{
Alina Vilk $\dot{e}^{1}$, Ugnė Grimutiené ${ }^{2}$, Lolita Grygalyte் ${ }^{2}$, Andrius Macas ${ }^{1}$ \\ ${ }^{1}$ Lietuvos sveikatos mokslu universitetas, Anesteziologijos klinika, \\ ${ }^{2}$ Lietuvos sveikatos mokslu universitetas, Medicinos fakultetas
}

Raktažodžiai: ketaminas, pooperacinis skausmas, perioperacinis nuskausminimas, stuburo fiksacijos operacija.

\begin{abstract}
Santrauka
Pooperacinio skausmo valdymas yra aktuali anesteziologijos tema. Dèl ilgos trukmès, plataus audinių praskyrimo, chirurginių implantų naudojimo stuburo operacijos siejamos su dideliu pooperaciniu skausmu. Prastai kontroliuojamas pooperacinis skausmas gali sukelti letinį skausmą, padidinti komplikacijų riziką, pailginti gydymo stacionare laikotarpị. Adekvačiai malšinamas skausmas gali turèti teigiamos itakos ankstyvajai reabilitacijai po operacijos. Dažniausiai skausmo malšinimui skiriami nesteroidiniai vaistai nuo uždegimo arba opioidiniai analgetikai. Opioidų vartojimas siejamas su tokiais nepageidaujamais reiškiniais kaip pykinimas, vėmimas, kvėpavimo slopinimas ir kt. Siekdami efektyviai malšinti skausmą, sumažinti nepageidaujamus reiškinius ir suminę suvartojamų opioidų ar kitų analgetikų dozę, galime rinktis ketaminą. Subanestetinemis dozėmis intraoperaciniu laikotarpiu vartojamas ketaminas gali efektyviai malšinti pooperacinị skausmą ir sumažinti opioidų poreikị.

Tyrimo tikslas - nustatyti intraoperacinès ketamino infuzijos skyrimo vertę, malšinant skausmą po stuburo fiksacijos operacijų ir jo ịtaką opioidų suvartojimui.

Metodika. Atlikta bandomoji perspektyvaus tyrimo studija, įtraukta 10 pacientų, kuriems buvo atliktos stuburo fiksacijos operacijos. Pacientai atsitiktiniu būdu suskirstyti ị dvi grupes: A grupé (kontrolinè, ketaminas nenaudojamas) ir B grupe (anestezijos metu naudojamas ketaminas). Po operacijos buvo vertinamas skausmo intensyvumas, opioidinès analgezijos poreikis ir kiekis, fiksuojami nepageidaujami reiškiniai.

Rezultatai. Vertinant skausmą iškart po operacijos, ketamino grupejje stebėtas statistiškai reikšmingai mažesnis
\end{abstract}

skausmas, nei kontrolinejje grupeje ( $\mathrm{P}=0,042)$. Kitomis dienomis ketamino grupés pacientai taip pat jaute mažesnị skausmą, tačiau tai nebuvo statistiškai reikšminga. Statistiškai reikšmingų opioidų suvartojimo skirtumų ar nepageidaujamų reiškinių tarp grupių nebuvo.

Išvados. Ketamino skyrimas operacijos metu gali turèti teigiamą efektą, malšinant pooperacinį skausmą po stuburo fiksacijos operacijų. Mūsų tyrimo duomenimis, mažų (subanestetinių) ketamino dozių skyrimas nedidina nepageidaujamų reiškinių rizikos.

\section{Ivadas}

Pooperacinis skausmas ir jo valdymas vis dar išlieka aktuali problema. Ūmiu pooperaciniu skausmu skundžiasi daugiau nei 80 proc. pacientų ir tik apie 50 proc. apklaustujų nurodè, kad skausmas buvo adekvačiai malšinamas $[1,2]$. Vienos iš skausmingiausių chirurginių procedūrų, siejamos su dideliu pooperaciniu skausmu, yra stuburo operacijos [3-5]. Šių operacijų metu plačiai praskiriami audiniai, naudojami chirurginiai implantai, tad nesant adekvataus nuskausminimo, pacientai skundžiasi stipriu skausmu, kuris gali tęstis keletą dienų po operacijos [4]. Prastai kontroliuojamas pooperacinis skausmas gali padidinti komplikacijų riziką, pailginti gydymo laiką stacionare ar sukelti lètinį skausmą [3]. Efektyvus skausmo valdymas turi įtakos ankstyvajai reabilitacijai, trumpesniam gydymosi stacionare laikui ir bendrai paciento savijautai.

Norint išvengti komplikacijų ir sumažinti pooperacinị skausmą, pacientams dažniausiai skiriami nesteroidiniai vaistai nuo uždegimo (NVNU) arba opioidiniai analgetikai. Opioidų vartojimas siejamas su daugeliu nepageidaujamų reiškinių, ịskaitant pykinimą, vėmimą, kvẻpavimo slopinimą ir kt. [6]. Siekdami sumažinti nepageidaujamą poveikị ir suminę suvartojamų opioidų bei kitų analgetikų dozę, efektyviam skausmo malšinimui galime rinktis kelių skirtingų pre- 
paratų derinị. Šiuose deriniuose gali būti vartojami NVNU, paracetamolis, opioidiniai analgetikai, ketaminas ir kt. [4,7]. Ketamino savybės gydyti skausmą yra plačiai tyrinèjamos. N-metilo D-aspartato (NMDA) receptorių antagonistas - ketaminas veikia blokuodamas NMDA receptorius centrineje ir periferineje nervų sistemose, sukelia tokius efektus kaip tiesioginè analgezija, mažina opioidų sukeltą hiperalgeziją ir toleranciją opioidams [6,7]. Analgetiniam efektui sukelti ketaminas skiriamas subanestetinèmis dozèmis. Nedidelèmis dozèmis intraoperaciniu laikotarpiu vartojamas ketaminas gali efektyviai malšinti pooperacini skausmą ir sumažinti opioidų poreiki $[8,9]$. Šio vaisto galima skirti vienkartinę intraveninę dozę, tęstinę intraveninę infuziją, intraveninę paciento kontroliuojamą analgeziją ar epidurinę infuziją [8]. Nors ketaminas gali sukelti nepageidaujamų reiškinių, tokių kaip haliucinacijos, košmaras, dvigubas matymas ir kt. $[7,10]$, vartojant subanestetinèmis dozėmis, šių reiškinių rizika yra minimali $[6,7,11]$.

Šioje bandomojoje studijoje buvo siekiama nustatyti ketamino, kaip papildomo analgetiko, reikšmę pooperacinio skausmo malšinimui ir opioidų suvartojimo mažinimui po stuburo fiksacijos operacijų.

Tyrimo tikslas - nustatyti intraoperacinès ketamino infuzijos vertę, malšinant skausmą po stuburo fiksacijos operacijų ir įtaką opioidų suvartojimui.

\section{Tyrimo medžiaga ir metodai}

Tyrimui atlikti gautas LSMU Bioetikos centro leidimas. Buvo atliekamas perspektyvusis atsitiktinių imčių dvigubai aklas tyrimas. İ bandomają studiją, vadovaujantis įtraukimo kriterijais, buvo įtraukta 10 pacientų.

İtraukimo kriterijai: 1) pacientai, stacionarizuoti ị Lietuvos sveikatos mokslų universiteto ligoninès Kauno klinikų (LSMUL KK) stuburo ir periferinių nervų neurochirurgijos skyrių stuburo fiksacijos operacijoms bendroje endotrachèjinejje nejautroje; 2) abiejų lyčių, vyresni nei 18 metų pacientai; 3) sąmoningi pacientai, kurie sutiko dalyvauti tyrime ir pasirašè sutikimo formą.

Tiriamieji operacijos dieną atsitiktinès atrankos būdu (ištraukiant voką) suskirstyti ị dvi lygias grupes:

A grupe - kontrolinè. Skiriami standartiškai bendrinei anestezijai naudojami vaistai: fentanilis, propofolis ir pasirinktas relaksantas (dažniausiai rokuroniumas). Ketaminas nevartojamas.

B grupè. Pacientams ịvadinès anestezijos metu su standartiškai bendrinei anestezijai naudojamais vaistais (fentanilis, propofolis ir pasirinktas relaksantas, dažniausiai rokuroniumas), indukcijos metu buvo suleista vienkartine 0,35 $\mathrm{mg} / \mathrm{kg}$ ketamino dozè $\mathrm{i} / \mathrm{v}$ ir operacijos antroje pusèje skirta vienkartinė $1 \mathrm{mg} / \mathrm{kg}$ dozé automatine švirkštine pompa per vieną valandą pagal LSMUL KK Anesteziologijos klinikoje patvirtintą ketamino vartojimo protokolą „Ūminio pooperacinio skausmo gydymo rekomendacija: ketamino vartojimas".

Visiems tiriamiesiems, nepriklausomai nuo to, i kurią grupe pateko, toliau taikytas ịprastinis LSMUL KK Anesteziologijos klinikoje patvirtintas pooperacinio skausmo mažinimo metodas. Operacijos pabaigoje visiems buvo skiriama paracetamolio ir NVNU (ketonalio arba ketolgano). Pooperaciniu laikotarpiu visiems tiriamiesiems toliau buvo taikomas bazinis gydymas pagal PSO trijų pakopų skausmo malšinimo rekomendacijas: pradedant nuo pirmos pakopos - skausmo malšinimo neopioidiniais vaistais (paracetamoliu ar NVNU), jei skausmas išlieka, pereinama prie antros pakopos - vidutinio stiprumo opioidų ir vèliausiai, jei išlieka stiprus skausmas, - stiprių opidoidų.

Pacientai tyrime dalyvavo operaciniu ir pooperaciniu laikotarpiu. Po operacijos 5 paras buvo renkami duomenys apie pacientų patiriamą skausmą, suvartojamas opioidų dozes ir galimas ketamino bei opioidų nepageidaujamas reakcijas. A ir B grupès lyginamos tarpusavyje ir formuojamos išvados.

Statistiné duomenų analizė atlikta naudojant duomenų analizės paketą IBM SPSS 24.0. Lyginant kokybinius rodiklius, naudotas chi kvadrato testas, nepriklausomų imčių palyginimui taikytas neparametrinis Mann - Whitney U testas. Duomenys vertinti kaip statistiškai reikšmingi, kai $p<0,05$.

\section{Tyrimo rezultatai}

Tyrime dalyvavo 10 tiriamujų: 7 moterys (70\%), 3 vyrai (30\%). Tiriamieji buvo suskirstyti ị lygias grupes: A grupę sudare 5 pacientai, B grupę -5 pacientai. Bendras tiriamuju amžiaus vidurkis buvo 54 metai, detaliau pacientų demografiniai duomenys pateikiami 1 lentelèje.

Vertinant skausmą iškart po operacijos, ketamino grupèje stebėtas statistiškai reikšmingai mažesnis skausmas, nei kontrolinèje grupejje $(\mathrm{P}=0,042)$. Pirmą vakarą po operacijos ketamino grupès pacientai taip pat vertino skausmą mažesniais balais, tačiau jis statistiškai reikšmingai nesiskyrè nuo kontrolinès grupès pacientų $(\mathrm{P}=0,167)$. Antros dienos rytą mažesni skausmo balai buvo kontrolinès grupès pacientų, tačiau jie nebuvo statistiškai reikšmingi $(\mathrm{P}=0,588)$. Kitomis dienomis, kai buvo vertinamas pacientų skausmas (antros dienos vakaras, trečia, ketvirta ir penkta dienos), ketamino grupès pacientai jautè mažesni skausmą, tačiau tai nebuvo statistiškai reikšmingas skirtumas (2 lentelè, 1 pav.).

Buvo vertinamas opioidų, tokių kaip doloblokas ir tramadolis, vartojimas pacientų nuskausminimui po operacijos. Iškart po operacijos ir pirmos dienos vakarą vienam kontrolinès grupès pacientui buvo skiriama dolobloko, trečią dieną po operacijos vienam kontrolinès grupès pacientui skirta tramadolio. Nei vienam ketamino grupès pacientui 
opioidinių nuskausminamųjų nebuvo skirta. Reikšmingų opioidų suvartojimo skirtumų tarp grupių nebuvo.

Buvo vertinamas galimo ketamino nepageidaujamo poveikio pasireiškimas po operacijos. Haliucinacijų nepatyre nei vienas tiriamasis. Košmariškus sapnus sapnavo 1 kontrolinès grupès pacientas, o ketamino grupès - nei vienas. Galvos skausmą po operacijos bent vieną dieną jautè visi 5 ketamino grupès pacientai, o kontrolinès grupès 4 iš 5 pacientų. Tachikardiją jaute 3 kontrolinès grupès ir nei vienas ketamino grupès tiriamasis. Pykinimą iškart po operacijos jaute 3 ketamino ir nei vienas kontrolinès grupès pacientas. Dvejinimąsi akyse nurode 2 kontrolinès ir nei vienas ketamino grupès pacientas. Reikšmingų ketamino nepageidaujamo poveikio apraiškų skirtumų po operacijos, lyginant grupes, nebuvo.

\section{Diskusija}

Skausmas po operacijos ir jo malšinimas itin aktualus anesteziologijos praktikoje. Atlikti tyrimai rodo, kad pooperacinis skausmas dažnai malšinamas nepakankamai $[1,2]$. Viena iš galimų problemų yra ta, kad skausmas nepakankamai įvertinamas. Pooperacinio skausmo įvertinimas svarbus, nes i jị atsižvelgiant galima parinkti adekvatų gydymo metodą. Patvirtintas skausmo vertinimo metodas yra skalių naudojimas: 1) skaitinè skausmo skalè (angl. numeric rating system, NRS) nuo 0 iki 10, kurioje 0 - nejaučia skausmo, 10 - nepakeliamas skausmas ir 2) vaizdo analogijos skalè (angl. visual analogue scale, VAS), kurioje tiesioje $10 \mathrm{~cm}$ linijoje: $0 \mathrm{~cm}$ - nèra skausmo, $10 \mathrm{~cm}$ - nepakeliamas skausmas.

Svarbu ne tik ịvertinti skausmą esamuoju momentu, bet ir numatyti, kurios procedūros gali sukelti didžiausią pooperacini skausmą. H. Gerbershagen ir bendraautoriai atliko tyrimą, kurio metu buvo vertinamas skausmas po skirtingų chirurginių procedūrų pirmą pooperacinę dieną. Tyrimo rezultatai parode, kad ortopedinès ir stuburo operacijos susijusios su vienu iš skausmingiausių pooperacinių periodų, kai skausmas pirmą dieną po stuburo fiksacijos operacijos vidutiniškai buvo vertinamas 6,61 balu pagal skaitinę skausmo skalę. Lyginant su kitomis chirurginemis procedūromis, skausmas po šių operacijų buvo vertinamas vienais iš aukščiausių balų [5]. Žinant tai, galima parinkti

1 lentelè. Tiriamųjų demografiniai duomenys.

\begin{tabular}{|l|l|c|c|}
\hline \multicolumn{2}{|l|}{ Požymis } & $\begin{array}{c}\text { Kontroline் } \\
\text { grupe }(\mathbf{n = 5})\end{array}$ & $\begin{array}{c}\text { Ketamino } \\
\text { grupe }(\mathbf{n}=\mathbf{5})\end{array}$ \\
\hline \multirow{2}{*}{ Lytis } & vyrai & $2(40 \%)$ & $1(20 \%)$ \\
\cline { 2 - 4 } & moterys & $3(60 \%)$ & $4(80 \%)$ \\
\hline Amžius (metai) & $55,60(7,77)$ & $52,80(9,89)$ \\
\hline \multicolumn{2}{|l|}{ KMI $\left(\mathrm{kg} / \mathrm{m}^{2}\right)$} & $32,26(5,32)$ & $32,74(3,52)$ \\
\hline
\end{tabular}

adekvačią analgeziją. Po šių chirurginių intervencijų skausmas dažniausiai gydomas NVNU arba opioidiniais analgetikais. Didelès dozės vaistų, ypač opioidinių analgetikų, gali sukelti nepageidaujamus reiškinius, tokius kaip pykinimas, vėmimas, šlapimo susilaikymas, kvėpavimo sutrikimas ir kitus [6,7]. Norint išvengti šių reiškinių ir sumažinti suminę suvartojamų analgetikų dozę, rekomenduojama rinktis sudètinę analgeziją, kai naudojami skirtingų grupių vaistai, kurie veikia skirtingus skausmo mechanizmus [7].

Renkantis sudètinę analgeziją, kaip vieną iš medikamentų galima vartoti ketaminą. Ketaminas yra bendrasis anestetikas, kuris dèl savo tiesioginio analgetinio efekto ir gebos užkirsti kelią nociceptinio kelio sujaudinimui CNS yra tinkamas malšinti pooperacinį skausmą. Būdamas NMDA receptorių antagonistu, jis mažina toleranciją opioidams ir jų sukeltą hiperalgeziją [4]. Viena iš priežasčių, ribojanti ketamino naudojimą, yra nepageidaujamų reiškinių, tokių kaip pykinimas, vėmimas, haliucinacijos ir kt. baimè. Naudojant ketaminą subanestetinèmis dozèmis, šių reiškinių rizika yra minimali $[8,12]$. Studijos rodo, kad ketaminas, naudojamas kaip papildomas analgetikas stuburo operacijų metu, gali mažinti pooperacini skausmą ir opioidų poreiki po operacijos, taip sumažindamas ir opioidams būdingų nepageidaujamų reakcijų pasireiškimo tikimybę $[8,9]$. Yra duomenų, kad intraoperacinis ketamino naudojimas gali sumažinti persistuojančio pooperacinio skausmo riziką $[1,9,13]$.

Atlikta nemažai tyrimų, kurie nagrinèja intraoperacinio ketamino vertę, malšinant pooperacinị skausmą. L. Miziara ir bendraautoriai tyré intraoperacinès ketamino infuzijos naudą, malšinant skausmą po laparoskopinès tulžies pūslès šalinimo operacijos. Jų gauti rezultatai parodè, kad ketaminą gavusių pacientų grupèje skausmo balai buvo mažesni 4 val. ir 12 val. po operacijos [14]. J. Mark Riddel ir bendraautoriai publikavo metaanalizę, kurios tikslas buvo ịvertinti jau turimus įrodymus apie mažų ketamino dozių vartojimą skausmingoms ortopedinèms operacijoms. Jų gauti rezultatai parodè, kad skausmas po viso sąnario protezavimo opera-

2 lentelè. Tiriamųų skausmo vertinimas.

\begin{tabular}{|l|c|c|c|}
\hline \multirow{2}{*}{ Stebejjimo laikas } & \multicolumn{2}{|c|}{$\begin{array}{c}\text { Skausmas pagal verbalinę } \\
\text { skausmo skalę }\end{array}$} & \multirow{2}{*}{ p } \\
\cline { 2 - 3 } & kontrolinė gr. & ketamino gr. & \\
\hline Iškart po operacijos & $6,2(2,78)$ & $2,0(2,74)$ & 0,042 \\
\hline 1 dienos vakaras & $6,2(2,28)$ & $4,2(1,01)$ & 0,167 \\
\hline 2 dienos rytas & $5,4(0,89)$ & $5,6(1,67)$ & 0,588 \\
\hline 2 dienos vakaras & $6,2(1,30)$ & $5,6(2,07)$ & 0,664 \\
\hline 3 diena & $6,4(2,30)$ & $4,2(1,64)$ & 0,133 \\
\hline 4 diena & $5,2(2,17)$ & $4,0(1,41)$ & 0,277 \\
\hline 5 diena & $5,2(1,79)$ & $3,6(1,52)$ & 0,063 \\
\hline
\end{tabular}


cijų išliko statistiškai reikšmingai mažesnis ketamino grupeje 48 valandas, o po stuburo operacijų 24 valandas [15]. Taip pat E. Brinck ir bendraautorių atlikta sisteminè literatūros analizè nustate, kad pacientai, gavę intraoperacinę ketamino infuziją, 24 val. po operacijos jautė mažesnį skausmą, lyginant su placebo (aukštas įrodymų lygmuo) [16]. Mūsų atlikta bandomoji studija taip pat parodè, kad pacientai, kuriems operacijos metu buvo skirtas ketaminas, iš karto po operacijos skausmą vertino mažesniu balu, lyginant su kontroline grupe $(2,0(2,74)$ ir 6,2 (2,78) atitinkamai, $\mathrm{P}=0,042)$. Mūsų studija skausmą vertino 5 dienas po operacijos. Statistiškai reikšmingas skausmo balų skirtumas buvo stebètas tik iš karto po operacijos. Kitomis dienomis vertintas skausmas buvo mažesnis, lyginant su kontroline grupe, tačiau tai nebuvo statistiškai reikšminga. Galima priežastis - maža bandomosios studijos imtis, tad norint nustatyti, ar skausmas visomis dienomis po operacijos yra statistiškai reikšmingai mažesnis, reikètų atlikti detalesnius tyrimus su didesne imtimi.

Mūsų tyrime vertintas opioidinių analgetiku, dolobloko ir tramadolio vartojimas pacientų nuskausminimui po operacijos. Doloblokas buvo skirtas vienam kontrolinès grupès pacientui iškart po operacijos ir pirmos dienos vakarą, tramadolis skirtas vienam kontrolinès grupès pacientui trečią dieną po operacijos. Pacientams, kuriems operacijos metu buvo skiriama ketamino, opioidinių analgetikų po operacijos neskirta, tačiau statistiškai reikšmingo skirtumo tarp grupių nenustatyta. P. Cengiz ir kt. atliktame tyrime nustatyta, kad pacientams, kuriems operacijos metu buvo skirta ketamino, papildomų opioidų nuskausminimui po operacijos prireikè vèliau, tačiau dozių suvartojimas tarp grupių nebuvo statistiškai reikšmingas [17]. E. Brinck ir bendraautorių atlikta sisteminè literatūros analizè parodè, kad opioidų suvartojimas po operacijos yra mažesnis (vidutinis įrodymų lygmuo), tačiau vertina tai dviprasmiškai dèl iškreipto opioidų suvartojimo pasiskirstymo [16].

Ketamino vartojimas siejamas su daugeliu nepageidaujamų reiškinių, todèl šiame tyrime taip pat norejome nustatyti, ar pacientams, kuriems buvo skirta ketamino, pasireiške šio

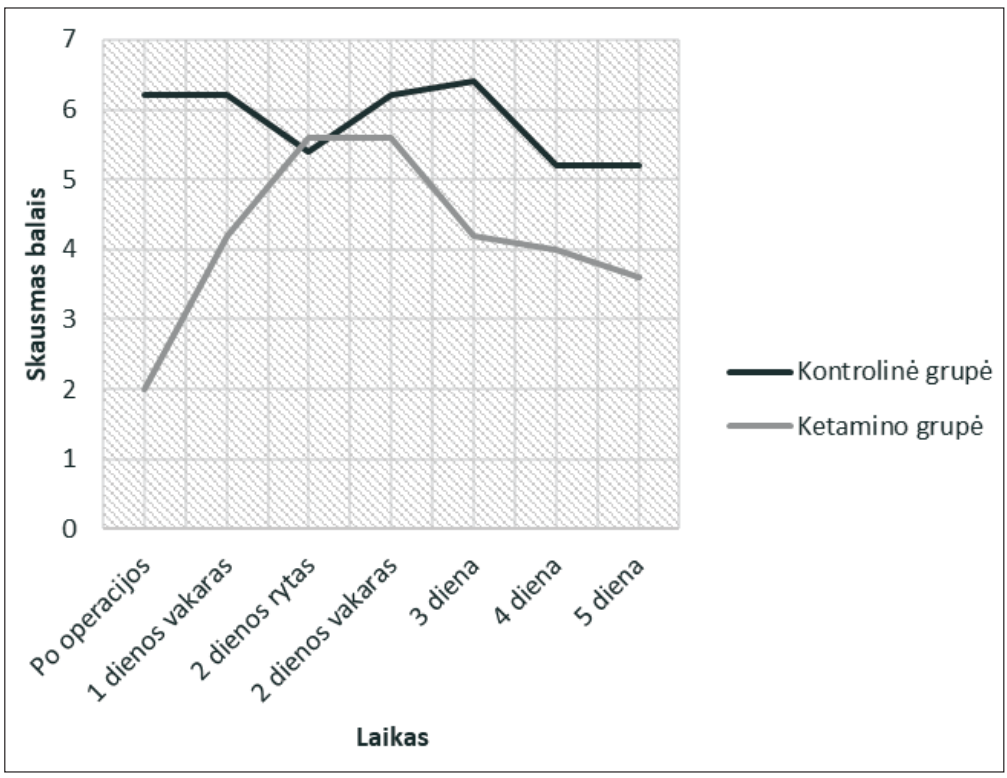

1 pav. Tiriamųų skausmo vertinimas

medikamento sukeliamas nepageidaujamas poveikis, toks kaip haliucinacijos, košmariški sapnai, pykinimas, galvos skausmas, dvejinimasis akyse, padidèjęs širdies susitraukimų dažnis ir kiti. Tyrimu nustatėme, kad nepageidaujamų reiškinių skirtumas tarp grupių nebuvo statistiškai reikšmingas. R. Loftus ir kt. atliktame tyrime statistiškai reikšmingo skirtumo tarp grupių nepageidaujamų reiškinių nebuvo [18], panašius tyrimo rezultatus aprašè P. Cengiz ir kiti [17]. Svarbu žinoti, kad ketamino nepageidaujami reiškiniai priklauso nuo dozès, todèl juos galime numatyti ir kontroliuoti $[12,16]$. Mūsų ir kituose minètuose tyrimuose skirtos dozès buvo nevienodos, tad galima manyti, jog tai yra viena iš priežasčių, lėmusių skirtingus rezultatus. Nei viena studija nepastebejjo tokių ketaminui būdingų reiškinių kaip haliucinacijų, košmariškų sapnų, dvejinimosi pasireiškimo statistinio reikšmingumo, todẻl galime daryti prielaidą, kad vartojant ketaminą subanestetinèmis dozėmis, šių reiškinių rizika yra minimali.

Šioje studijoje buvo pastebèta, kad ketaminas turi įtakos pooperacinio skausmo malšinimui - pacientai, kuriems operacijos metu buvo skirta ketamino, nurodè mažesnius skausmo balus po operacijos. Mokslinėje literatūroje yra tyrimų, kurie patvirtina ši rezultatą, tad ketamino galima skirti itin skausmingų operacijų metu, kai tikimasi didelio pooperacinio skausmo. Nepageidaujami ketamino reiškiniai tarp grupių nebuvo statistiškai reikšmingi. Nenustatyta ir statistiškai reikšmingo skirtumo tarp opioidinių analgetikų suvartojimo. Mūsų tyrime skirtos ketamino dozès, lyginant su kitais tyrimais, gali nesutapti. Nei viename iš tyrimų neatsižvelgta ị paciento amžių ar gretutines ligas, kurios gali turèti įtakos ketamino metabolizmui ir poveikiui [19]. Šiuos mūsų rezultatus reikètų vertinti rezervuotai. Norint sužinoti daugiau apie intraoperacinio ketamino poveiki, numatoma atlikti detalesnius tyrimus su didesne imtimi. 


\section{Išvados}

Ketamino skyrimas operacijos metu gali turèti teigiamą efektą, malšinant pooperacinį skausmą po stuburo fiksacijos operacijų. Mūsų tyrimo duomenimis, ketamino mažų (subanestetinių) dozių skyrimas nepadidina nepageidaujamų reiškinių rizikos.

\section{Literatūra}

1. Rawal N. Current issues in postoperative pain management. Eur J Anaesthesiol 2016;33(3):160-171. https://doi.org/10.1097/EJA.0000000000000366

2. Gan TJ, Habib AS, Miller TE, White W, Apfelbaum JL. Incidence, patient satisfaction, and perceptions of post-surgical pain: results from a US national survey. Current Medical Research and Opinion 2014;30(1):149-160. https://doi.org/10.1185/03007995.2013.860019

3. Dunn LK, Durieux ME, Nemergut EC. Non-opioid analgesics: novel approaches to perioperative analgesia for major spine surgery. Best Pract Res Clin Anaesthesiol 2016;30(1):79-89. https://doi.org/10.1016/j.bpa.2015.11.002

4. Bajwa SS, Haldar R. Pain management following spinal surgeries: an appraisal of the available options. J Craniovert Jun Spine 2015;6:105-10.

https://doi.org/10.4103/0974-8237.161589

5. Gerbershagen HJ, Aduckathil S, van Wijck AJM, Peelen LM, Kalkman CJ, Meissner W. Pain intensity on the first day after surgery: a prospective cohort study comparing 179 surgical procedures. Anesthesiology 2013;118(4):934-944.

https://doi.org/10.1097/ALN.0b013e31828866b3

6. Pendi A, Field R, Farhan SD, Eichler M, Bederman SS. Perioperative ketamine for analgesia in spine surgery: a metaanalysis of randomized controlled trials. Spine (Phila Pa1976) 2018;43:E299-307.

https://doi.org/10.1097/BRS.0000000000002318

7. Devin CJ, McGirt MJ. Best evidence in multimodal pain management in spine surgery and means of assessing postoperative pain and functional outcomes. Journal of Clinical Neuroscience 2015;22(6):930-938.

https://doi.org/10.1016/j.jocn.2015.01.003

8. Jouguelet-Lacoste J, La Colla L, Schilling D, Chelly JE. The use of intravenous infusion or single dose of low-dose ketamine for postoperative analgesia: a review of the current literature. Pain Medicine 2015;16(2):383-403.

https://doi.org/10.1111/pme.12619

9. Rivkin A, Rivkin MA. Perioperative nonopioid agents for pain control in spinal surgery. American Journal of Health-System Pharmacy 2014;71(21):1845-1857.

https://doi.org/10.2146/ajhp130688

10. Gabriel R, Swisher M, Sztain J, Furnish T, Ilfeld B, Said E. State of the art opioid-sparing strategies for post-operative pain in adult surgical patients. Expert Opinion on Pharmacotherapy
2019;20(8), 949-961.

https://doi.org/10.1080/14656566.2019.1583743

11. Schwenk ES, Goldberg SF, Patel RD, et al. Adverse drug effects and preoperative medication factors related to perioperative low-dose ketamine infusions. Reg Anesth Pain Med 2016;41(4):482-487.

https://doi.org/10.1097/AAP.0000000000000416

12. Allen CA, Ivester JR. Ketamine for pain management - side effects \& potential adverse events. Pain Management Nursing 2017;18(6):372-377

https://doi.org/10.1016/j.pmn.2017.05.006

13. Mcnicol ED, Schumann R, Haroutounian S. Ketamine for prevention of PPSP. Acta Anaesthesiol Scand 2014;58:1199-1213. https://doi.org/10.1111/aas.12377

14. Miziara LE, Simoni RF, Esteves LO, Cangiani LH, Grillo-Filho GF, Paula AG. Efficacy of continuous $\mathrm{S}(+)$ - ketamine infusion for postoperative pain control: a randomized placebo-controlled trial. Anesthesiol Res Pract 2016;2016:6918327.

https://doi.org/10.1155/2016/6918327

15. Riddel JM, Trummel JM, Onakpoya IJ. Low-dose ketamine in painful orthopaedic surgery: a systematic review and metaanalysis. British Journal of Anaesthesia 2019;123(3).

https://doi.org/10.1016/j.bja.2019.05.043

16. Brinck EC, Tiippana E, Heesen M, et al. Perioperative intravenous ketamine for acute postoperative pain in adults. Cochrane Database Syst Rev 2018;12(12):CD012033. https://doi.org/10.1002/14651858.CD012033.pub4

17. Cengiz P, Gokcinar D, Karabeyoglu I, Topcu H, Cicek GS, Gogus N. Intraoperative low-dose ketamine infusion reduces acute postoperative pain following total knee replacement surgery: a prospective, randomized, placebo-controlled trial. J Coll Physicians Surg Pak 2014;24(5):299-303.

18. Loftus RW,Yeager MP, Clark JA, Brown JR, Abdu WA, Sengupta DK, Beach ML. Intraoperative ketamine reduces perioperative opiate consumption in opiate-dependent patients with chronic back pain undergoing back surgery. Anesthesiology 2010;113:639-646.

https://doi.org/10.1097/ALN.0b013e3181e90914

19. Mion G, Villevieille T. Ketamine pharmacology: an update (pharmacodynamics and molecular aspects, recent findings). CNS Neurosci Ther 2013;19(6):370-80.

https://doi.org/10.1111/cns.12099

\section{PERIOPERATIVE PAIN MANAGEMENT USING INTRAOPERATIVE KETAMINE DURING SPINAL FUSION SURGERY: A PILOT STUDY}

A. Vilkè, U. Grimutiené, L. Grygalytė, A. Macas

Keywords: ketamine, post-operative pain, perioperative pain management, spinal fusion surgery.

Summary

Post-operative pain is a relevant topic in anesthesiology. Spinal surgeries are considered to be one of the most painful inter- 
ventions. Poorly controlled postoperative pain can lead to a higher risk of complications, increased length of hospital stay and even the development of chronic pain. Adequate pain control is positively linked to early rehabilitation after the surgery. NSAID's and opioids are most commonly used for pain management. Opioids are often linked to many side effects including nausea, vomiting, respiratory depression etc. Perioperative ketamine couldbe used to achieve adequate pain control, reduce the incidence of unwanted side effects and reduce opioid demand.

The aim of this study was to determine the value of intraoperative ketamine infusion in pain management after spinal fusion surgery and it's effect on opioid consumption.

Methods: A perspective pilot study was performed with 10 patients who underwent spinal fusion surgery. Patients were randomly assigned to group A (control group) or group B (ketamine used intraoperatively). We evaluated pain scores, opioid consumption and side effects.
Results: Pain scores were significantly lower immediately after surgery $(\mathrm{P}=0,042)$. The following days patients who received ketamine described lower pain scores however the results were not statistically significant. The difference between groups regarding opioid consumption or the prevalence of side effects were not statistically significant.

Conclusions: Ketamine used perioperatively has a positive impact on acute postoperative pain management after spinal fusion surgery. We didn't observe ketamine administered in low (subanaesthetic) doses to increase the incidence of side effects.

Correspondence to: alina.vilke@1smuni.1t

Gauta 2021-02-18 